SŁawomir Dorocki, Piotr RaźNiak

Uniwersytet Pedagogiczny, Kraków, Polska

DANIEL OBIREK

Krakowska Akademia im. A.F. Modrzewskiego, Kraków, Polska

\title{
Rozwój infrastruktury narciarskiej w Polsce i na terenie Podhala w świetle badań ankietowych
}

\author{
Development of ski infrastructure in Poland \\ and the Podhale region on the basis of surveys
}

\begin{abstract}
Streszczenie: W okresie zachodzących współcześnie przemian ekonomicznych, społecznych, technologicznych i kulturowych następuje zmiana sposobu spędzania czasu wolnego. Cechą współczesnego wypoczynku i rekreacji, a zarazem kierunkiem ich rozwoju, jest zróżnicowana aktywność sportowa na świeżym powietrzu. Dzięki większej zamożności i mobilności mieszkańców krajów rozwiniętych, powszechnemu dostępowi do specjalistycznego sprzętu oraz szerokiej gamie oferowanych usług spędzania czasu wolnego usługi turystyczne stały się dziś egalitarne, tworząc z turystyki zjawisko masowe. Turystyka jest obecnie jedną z prężniej rozwijających się gałęzi gospodarki wielu państw świata i ma coraz większy wpływ na kreowanie rozwoju lokalnego poprzez wzrost gospodarczy i zwiększanie zatrudnienia.

Obserwując popularyzację aktywnego sposobu spędzania wolnego czasu w Polsce, widzimy wzrastające zainteresowanie zwłaszcza sportami zimowymi. Narciarstwo i snowboarding są coraz bardziej lubianymi formami spędzania aktywnego wypoczynku w okresie zimowym. W odpowiedzi na zgłaszany popyt w Polsce powstaje coraz więcej ośrodków narciarskich. Wzmożony ruch turystyczny w okresie zimowym, a także konkurencja, wymuszają na właścicielach ośrodków narciarskich nowe inwestycje w celu zaspokojenia rosnących potrzeb użytkowników tych ośrodków. Konkurencyjność w tym sektorze rodzi w przedsiębiorcach konieczność poszukiwania nowych i innowacyjnych rozwiązań powodujących usprawnienia i udogodnienia dla użytkowników, oferując tym samym coraz atrakcyjniejsze formy spędzania wolnego czasu. Celem niniejszej pracy jest ocena, w oparciu o przeprowadzone badania terenowe, bieżącego stanu infrastruktury narciarskiej wraz z usługami komplementarnymi oraz oczekiwań użytkowników na terenie najbardziej popularnego regionu narciarskiego w Polsce, jakim jest Podhale. W opracowaniu poddano również analizie bariery rozwojowe ośrodków narciarskich wraz z oczekiwaniami ich użytkowników.
\end{abstract}

Abstract: In times of contemporary economic, social, technological, and cultural changes, what also
changes is the way of spending free time. A feature of the modern leisure and recreation, and also
the direction of their development is the diverse sporting activities undertaken outside of households.
Furthermore, due to the greater prosperity and mobility of inhabitants in developed countries, wide ac-
cess to specialized equipment and a wide range of services offered, tourist services have become more 
egalitarian, creating the phenomenon of mass tourism. Tourism is now one of the most dynamically developing sectors of economy in many countries in the world and has an increasing impact on local development through economic growth and an increase in employment.

In Poland, in terms of popularizing active way of spending free time a progressive interest in winter sports has been observed. Skiing and snowboarding are becoming the preferred forms of spending time actively in winter. In response to the reported demand in Poland, more and more ski resorts are opened. Increased tourist traffic in winter, as well as new competition, forces the owners of ski resorts to undertake new investments, in order to meet the growing needs of users of such centers. Competitiveness in this sector causes the entrepreneurs to seek new and innovative solutions, which result in improvements and enhancements for users, thus offering more attractive ways of spending free time. The purpose of this paper is to assess the current state of ski infrastructure with complementary services and users' expectations in the most popular ski resort in Poland, which is the Podhale Region. This is done on the basis of fieldwork carried out in said region. Also analyzed in the study are developmental barriers of ski resorts and expectations of users.

Słowa kluczowe: narciarstwo; Podhale; sporty zimowe; stacja narciarska

Keywords: skiing; Podhale region; winter sports; ski station

\section{WSTĘP}

W świetle zachodzących współcześnie przemian ekonomicznych, społecznych, technologicznych i kulturowych wiele dotychczasowych poglądów dotyczących sposobu spędzania czasu wolnego uległo zmianie. Obserwujemy zmiany w tendencji popytu i podaży usług czasu wolnego, przy jednoczesnej ich globalnej unifikacji. Globalne megatrendy turystyczne rozumiane są jako globalne tendencje obserwowane na rynku turystycznym całego świata. Cechą współczesnego wypoczynku i rekreacji, a zarazem kierunkiem ich rozwoju, jest wielorako rozumiana aktywność sportowa. Szczególnie dużo uwagi poświęca się ostatnio trendom w aktywności fizycznej na świeżym powietrzu. (Olchowik, 2006). Usługi turystyczne stały się dziś egalitarne również dzięki większej zamożności i mobilności mieszkańców krajów rozwiniętych, powszechnemu dostępowi do specjalistycznego sprzętu oraz szerokiej gamie oferowanych usług spędzania czasu wolnego, tworzącym z turystyki zjawisko masowe. Istniejąca współcześnie segmentacja turystyki kwalifikowanej nie jest już tak wyraźna jak jeszcze kilkanaście lat temu (Preisler, 2011). Usługi związane z turystyką i rekreacją są zjawiskiem wielopłaszczyznowym, łączącym w sobie aspekty społeczne, gospodarcze i kulturowe, a wysoki poziom infrastruktury może wpływać na liczbę przyjeżdżających osób (Raźniak, 2013a). Usługi te są obecnie jedną z prężniej rozwijających się gałęzi gospodarki wielu państw świata i mają coraz większy wpływ na kreowanie rozwoju lokalnego, poprzez wzrost gospodarczy i zwiększanie zatrudnienia (Krupa, Wołowiec, 2010).

Obserwując popularyzację aktywnego sposobu spędzania wolnego czasu w Polsce, widzimy wzrastające zainteresowanie sportami zimowymi. Narciarstwo i snowboarding są coraz bardziej lubianymi formami aktywnego wypoczynku w okresie zimowym. Równocześnie w odpowiedzi na popyt w Polsce powstaje coraz więcej ośrodków narciarskich. Wzmożony ruch turystyczny w okresie zimowym, a także konkurencja, wymusza na właścicielach 
ośrodków narciarskich nowe inwestycje zaspokajające rosnące potrzeby użytkowników tych ośrodków. Konkurencyjność w tym sektorze rodzi w przedsiębiorcach konieczność poszukiwania nowych, innowacyjnych rozwiązań powodujących usprawnienia i udogodnienia dla użytkowników, oferujących tym samym coraz atrakcyjniejsze formy spędzania wolnego czasu (Helešic, 2014). Celem niniejszej pracy jest ocena bieżącego stanu infrastruktury narciarskiej wraz z usługami komplementarnymi oraz oczekiwań klientów ośrodków narciarskich w zakresie infrastruktury i usług narciarskich na terenie najbardziej popularnego regionu narciarskiego w Polsce, jakim jest Podhale. W opracowaniu poddano również analizie plany rozwojowe ośrodków narciarskich.

W pracy wykorzystano metodę kwestionariusza wywiadu oraz wywiadu pogłębionego. Badania ankietowe przeprowadzone zostały przez jednego z autorów w 12 wybranych ośrodkach narciarskich na Podhalu w sezonie zimowym 2011/2012 i 2012/2013. W dziesięciu ośrodkach przebadano po 10 losowo wybranych osób. Natomiast w przypadku Kotelnicy i Kaniówki w Białce Tatrzańskiej przeprowadzono po 30 wywiadów w każdej z nich. Taki wybór wynikał z faktu, że oba ośrodki działają w systemie wspólnej karty TatrySki. Systemem wspólnej karty TatrySki objęte są: Bania, Kotelnica i Kaniówka w Białce Tatrzańskiej oraz Hawrań w Jurgowie i Czorsztyn-Ski w Kluszkowcach. Wybór Kotelnicy i Kaniówki spowodowany był również tym, oprócz wymienionej już wspólnej karty, że Kotelnica to największy, a Kaniówka - najmniejszy z ośrodków objętych wspólną kartą. Badaniom zostało poddanych 160 losowo wybranych osób, w tym 99 mężczyzn i 61 kobiet. Najmłodszy respondent miał 18 lat, natomiast najstarszy - 74 lata. W kwestionariuszu zawarto pytania, wśród których uwzględniono następujące elementy: ocenę wyciągów, koszt karnetów, różnorodność tras, nachylenie stoku, szerokość i długość tras, liczbę miejsc parkingowych oraz usługi komplementarne, takie jak: zaplecze gastronomiczne i wypożyczalnia sprzętu. Badanie gestorów odbywało się na podstawie osobno przygotowanego kwestionariusza wywiadu. Pytania zadawane właścicielom ośrodków narciarskich dotyczyły: planów inwestycyjnych, trudności napotykanych przy realizacji nowych inwestycji, a także problemów związanych z bieżącym funkcjonowaniem ośrodków. Pytania badały także dynamikę liczby osób odwiedzających stacje w ostatnich trzech sezonach, jak również sposoby zaśnieżania i bieżącego utrzymania stoków.

\section{Narciarstwo w Polsce}

Za pioniera narciarstwa w Polsce przyjmuje się Stanisława Barabasza, który pod koniec XIX wieku rozpoczął popularyzacje turystyki narciarskiej w Tatrach. Pierwsze polskie organizacje narciarskie powstały w 1907 roku i były to: Karpackie Towarzystwo Narciarzy we Lwowie oraz Sekcja Narciarska Towarzystwa Tatrzańskiego w Zakopanem (Baran, 1985). W 1907 roku urządzono pierwsze zawody narciarskie na Kalatówkach, a dalszy rozwój różnych form narciarstwa nastąpił w okresie międzywojennym, kiedy Zakopane stało się ważnym ośrodkiem narciarskim. W 1929 i 1939 roku odbyły się w Zakopanem Mistrzostwa 
Świata FIS. Z czasem polskie narciarstwo rozprzestrzeniło się na wszystkie polskie góry, w którym to procesie dużą rolę odegrał promujący ten sport Polski Związek Narciarski (Baran, 1985). Drugim ważnym ośrodkiem sportów zimowych była Krynica, która już w 1924 roku była gospodarzem V Mistrzostw Polski w narciarstwie (Dorocki, Brzegowy, 2013 ). W 1936 roku uruchomiono kolej linową na Kasprowy Wierch, aktywizując sporty zimowe w Zakopanem. Sukces ten oraz wzrastająca liczba miłośników nart wpłynęły na budowę dwóch kolejnych kolei linowych: na Górę Parkową w Krynicy (1936 rok) i na Gubałówkę w Zakopanem (1938 rok). Były także zamierzenia budowy kolei z Kalatówek na przełęcz Wrótka, ale plany zniweczyła wojna. W latach powojennych masowo ruszyła budowa ośrodków narciarskich. Wybudowano kolej gondolową na Szyndzielni w Beskidzie Śląskim, koleje krzesełkowe na Hali Gąsienicowej i na Nosal, na Kopę i Szrenicę w Karkonoszach oraz na Skrzyczne w Szczyrku (Baran, 1985). W połowie lat 60. XX wieku nastąpiło udoskonalenie sprzętu narciarskiego, dzięki czemu narciarze mogli coraz sprawniej poruszać się po trasach. Zaczęły się pojawiać wyciągi narciarskie zaczepowe, zwane potocznie wyrwirączkami, a jednocześnie z nimi wyciągi orczykowe (dwuosobowe) i talerzykowe (jednosobowe). Rosła liczba osób uprawiających turystykę narciarską, dla których budowano obiekty, kompleksy obsługujące przyjeżdżających narciarzy. W latach 70 . XX wieku powstała duża liczba funkcjonujących do dzisiaj wyciągów oraz koleje krzesełkowe na: Czantorię (1968 rok), Butorowy Wierch (1977 rok) i Tobołów (1982 rok). Dzięki ówczesnym kopalniom węgla kamiennego i innym państwowym zakładom przemysłowym nastąpiła rozbudowa ośrodków na Śląsku, takich jak: Szczyrk i Wisła (Zuzańska-Żyśko, 2005; Zuzańska-Żyśko, 2006), oraz w Karpatach: Sucha Dolina w Piwnicznej-Kosarzyskach, Lubomierz, Szczawa i Kasina Wielka w Beskidzie Wyspowym oraz Słotwiny w Krynicy (Baran, 1985).

Współcześnie turystyka narciarska poprzez swój masowy charakter jest jednym z głównych czynników wspomagających rozwój społeczno-gospodarczy wielu miejscowości na obszarach górskich (Kurek, 2004). Doświadczenia ośrodków narciarskich świata i Europy wskazują, że inwestycje w infrastrukturę dla narciarstwa zjazdowego przynoszą stosunkowo szybki zwrot poniesionych nakładów finansowych, który - według właścicieli ośrodka narciarskiego Master Ski w Tyliczu - wynosi mniej niż 5 lat. Obecnie obserwuje się w Polsce bardzo duże zainteresowanie inwestorów, a także władz samorządowych, tworzeniem nowej lub modernizowaniem już istniejącej infrastruktury dla tej formy turystyki (Chudy-Hyski 2005).

Rozwój narciarstwa nastąpił dzięki przyjęciu przez Polaków zachodniego systemu urlopowego złożonego z dwóch wyjazdów w ciągu roku. Pierwszy odbywa się latem, w celach wypoczynkowych lub krajoznawczych, drugi - zimą, kiedy to odpoczywamy aktywnie. Z sondażu TNS OBOP wynika, że przeciętnie na nartach lub na snowboardzie jeździ co piąty Polak. Rodzimy narciarz wyjeżdża na narty najczęściej dwa razy w roku (38\%), a jego pobyt w górach trwa nie dłużej niż tydzień (54\%.). Choć zainteresowanie wyjazdami zimowymi wśród polskich turystów jest wciąż stosunkowo niewielkie (ok. 18\% Polaków), wyjazdy narciarskie są stałą częścią oferty większości touroperatorów. Propozycja wyjazdu na narty skierowana jest przede wszystkim do zamożnego klienta, dla którego jest to drugi, poza letnim, urlop w roku. W Polsce narciarskie usługi rekreacyjne są dalej dobrem prestiżowym. Dlatego ich konsumpcja bardzo często zaspokaja potrzebę demonstracji statusu materialnego 
nabywcy. Efekt ten rośnie wraz z ceną nabywanych dóbr. Wzrost cen usług narciarskich może zatem przyczynić się niekiedy również do wzrostu popytu na te usługi (Puciato, 2010).

W Polsce w ciągu ostatnich kilku lat można zauważyć gwałtowny wzrost liczby ośrodków i wyciągów narciarskich. W 2014 roku według wykazu GOPR i TOPR na terenie kraju funkcjonowało ok. 181 wyciągów narciarskich zlokalizowanych ze względu na ukształtowanie terenu w południowej części kraju, w województwach: dolnośląskim, śląskim, małopolskim i podkarpackim, w górskich regionach Sudetów i Karpat (ryc. 1).

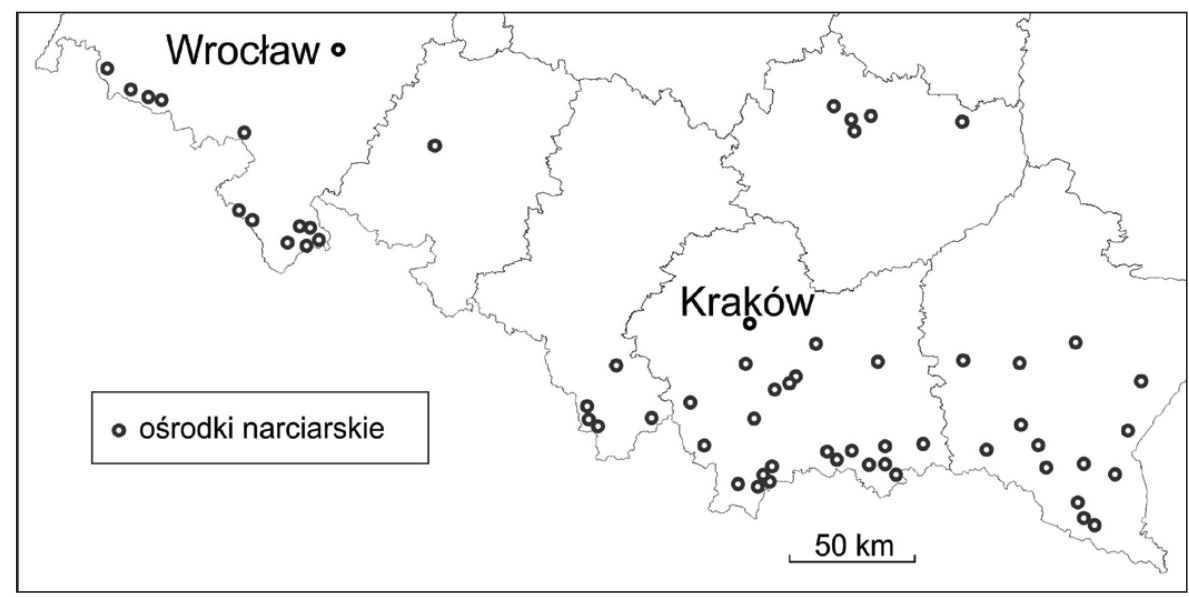

Ryc. 1. Rozmieszczenie ośrodków narciarskich w regionach górskich Polski

Źródło: opracowanie własne na podstawie danych internetowych

Województwo dolnośląskie od ponad 100 lat jest regionem silnie związanym z narciarstwem i przyciąga na swoje stoki narciarzy z całej Europy. Głównym ośrodkiem regionu jest Zieleniec, położony na stokach Šerlicha (1025 m n.p.m.) i Zielonego Garbu (1026 m n.p.m.), gdzie znajduje się 20 wyciągów orczykowych i talerzykowych, dobrze przygotowane trasy narciarskie oraz dobrze funkcjonujące szkółki, serwisy narciarskie i wypożyczalnie sprzętu zimowego. Innym popularnym miejscem jest Jugów w Górach Sowich. Istnieje tu możliwość uprawiania narciarstwa zarówno biegowego, jak i zjazdowego. Znajduje się tutaj około 2,5 km nartostrad oraz funkcjonuje system sztucznego zaśnieżania stoków. Również Karpacz posiada znakomite warunki do uprawiania sportów zimowych i innych form rekreacji. Usytuowanych jest tu kilkanaście stoków narciarskich wraz z rozbudowaną infrastrukturą turystyczną i bazą wypoczynkową. Bardziej wymagający narciarze mogą korzystać z usług kompleksu narciarskiego Śnieżka, wyposażonego w osiem wyciągów, w tym dwóch krzesełkowych. Na skraju dwóch pasm Sudetów Zachodnich: Karkonoszy i Gór Izerskich, znajduje się Szklarska Poręba, która jest znanym miejscem do uprawiania sportów zimowych, przede wszystkim narciarstwa zjazdowego i biegowego. Jeden z większych kompleksów w tym rejonie - Szrenica Ski Arena - oferuje narciarzom $12 \mathrm{~km}$ tras zjazdowych, trzy koleje liniowe krzesełkowe (dwie dwuosobowe i jedną sześcioosobową). Natomiast Świeradów Zdrój oraz znajdujący się w nim ośrodek narciarski oferują 2500 m tras zjazdowych o różnych stopniach 
trudności. Trasy są oświetlone i naśnieżane w razie potrzeby armatkami śnieżnymi, a od 2008 roku kompleks wyposażony jest w kolej linowo-gondolową.

Następnym regionem narciarskim Polski jest województwo małopolskie. Małopolska posiada największą liczbę wyciągów narciarskich na terenie Polski, zlokalizowane są na jej terenie największe ośrodki narciarskie w kraju. Wynika to zarówno z atrakcyjności walorów przyrodniczych, jak i ogólnego rozwoju usług turystycznych (Dryglas, Wach 2007a; Dryglas, Wach, 2007b). W województwie małopolskim popularne ośrodki narciarskie usytuowane są przede wszystkim w Tatrach i na Podhalu, które zostaną omówione w dalszej części pracy.

W głównym paśmie Karpat, w Beskidzie Sądeckim, nowoczesnym i rozbudowanym ośrodkiem narciarskim jest Jaworzyna Krynicka w Krynicy Zdrój. Ośrodek wyposażony jest w nowoczesną kolej gondolową, kolej krzesełkową, 9 wyciągów narciarskich i 8 tras zjazdowych o zróżnicowanym stopniu nachylenia i trudności, najdłuższą w Polsce trasę oświetloną oraz najdłuższą trasę rodzinną. W Krynicy istnieją również inne ośrodki narciarskie, m.in. na Słotwinach oraz w centrum miasta (ośrodek Henryk). Innym ważnym regionem dla narciarstwa rodzinnego staje się Tylicz, z takimi ośrodkami narciarskimi jak Tylicz Ski i Master Ski. Na terenie Krynicy powstały w ostatnich latach również liczne trasy do narciarstwa klasycznego. W dwóch sąsiadujących z uzdrowiskiem miejscowościach: Muszynie i Wierchomli zlokalizowana jest Stacja Narciarska Dwie Doliny Muszyna-Wierchomla. Kompleks ten powstał w 1998 roku na terenie Wierchomli, rozwijając zarówno usługi narciarskie oraz SPA, jak i turystykę konferencyjną (Dorocki, 2007). Ośrodek na stokach o powierzchni 100 ha oferuje 10 wyciągów (dwa krzesełkowe, sześć orczykowych, dwa linowe). Główny wyciąg krzesełkowy ma 1600 m długości i jest jednym z najdłuższych w Polsce.

W powiecie limanowskim znajdują się: stacja narciarska Śnieżnica w Kasinie Wielkiej, Laskowa-Kamionna oraz Limanowa Ski na Łysej Górze w Limanowej, Lubomierz, Niedźwiedź, Tymbark i Szczawa. Tuż przy granicy Gorczańskiego Parku Narodowego, w Koninkach na grzbiecie Tobołowa (964 m n.p.m.) znajduje się stacja narciarska Koninki Ski. W powiecie myślenickim atrakcją dla początkujących narciarzy jest kompleks narciarski Siepraw Ski w Sieprawiu, a dla bardziej wymagających stacja narciarska Zarabie Sport na myślenickiej górze Chełm. Zlokalizowane są tu dwie trasy o długościach 900 m i 1100 m, na które dowozi narciarzy czteroosobowa kolejka krzesełkowa.

W Beskidach Zachodnich w pobliżu Babiej Góry w Zawoi powstał kompleks narciarski Zawoja-Czatoża i Mosorny Groń (1045 m n.p.m.), z koleją krzesełkową o długości 1380 m. Innymi znanymi ośrodkami Małopolski są: Szczawnica, Rytro czy Magura Małastowska w Beskidzie Niskim.

Województwo śląskie nie należy do typowych obszarów górskich, ale leżące na jego terenie Pogórze Śląskie, Beskid Śląski i Beskid Żywiecki stanowią od wielu lat największą zimową i letnią bazę wypoczynkową dla mieszkańców Śląska (Petryszyn, Zuzańska-Żyśko, 2009; Pytel, Tkocz, Zuzańska-Żyśko, 2009). W latach 70. XX wieku przedsiębiorstwa górnicze budowały tam swoje bazy wypoczynkowe, dzięki temu powstało wiele dobrze wyposażonych i funkcjonujących do dziś ośrodków narciarskich. Jednym z nich jest Pilsko w Korbielowie w masywie Pilska (1557 m n.p.m.), z blisko 20 km tras zjazdowych. Innym jest góra Żar w Międzybrodziu Żywieckim, z koleją linowo-terenową, trasą o długości $1600 \mathrm{~m}$ z wyciągiem orczykowym oraz tzw. ruchomą taśmą dla małych dzieci. W Szczyrku 
funkcjonują 2 duże ośrodki narciarskie usytuowane między Małym i Dużym Skrzycznem. Były to w latach 70. i 80. XX wieku najlepiej wyposażone i przygotowane ośrodki narciarskie w Polsce (Centralny Ośrodek Sportu oraz Górniczy Ośrodek Narciarski). Oba są czynne do dziś, lecz ich stan nie zmienił się od lat 80 . XX wieku. Jednym z najbardziej znanych polskich ośrodków narciarskich jest Wisła. Największe stacje narciarskie w tym mieście to Ośrodek Narciarski Stożek, Stacja Narciarska Cieńków oraz Soszów.

Województwo podkarpackie w porównaniu do pozostałych regionów południowej Polski nie posiada zbyt rozbudowanej infrastruktury narciarskiej. Baza wyciągów narciarskich jest przede wszystkim rozmieszczona w Bieszczadach i Podgórzu Karpackim. Główne ośrodki narciarskie tego regionu to: Przemyśl, Kiczera Puławy Górne, Gromadzyń i Laworta w Ustrzykach Dolnych.

W związku z dużym zainteresowaniem sportami zimowymi wyciągi lokalizowane są również na terenach nizinnych (Pomorze, Warmia) oraz w pobliżu dużych aglomeracji miejskich (np. Warszawa, Katowice, Poznań).

Według przeprowadzonego rankingu ośrodków narciarskich w Polsce w 2013 roku (tab. 1) największą popularnością wśród narciarzy cieszą się stoki na Podhalu i w Tatrach, w Beskidach (Sądecki i Śląski). Na pierwszych miejscach znajdują się duże ośrodki narciarskie oferujące stoki o zróżnicowanych trasach oraz zapewniające pełną gamę usług. Innymi popularnymi ośrodkami są wyciągi narciarskie położone w pobliżu dużych aglomeracji miejskich lub popularnych miejscowości wypoczynkowych. Są to mniejsze ośrodki, oferujące zazwyczaj trasy o małej trudności oraz kierujące ofertę dla rodzin i dzieci. Popularne są również wyciągi lokalizowane w regionach o ubogiej infrastrukturze narciarskiej.

Najbardziej ogólne wymagania dotyczące zagospodarowania terenów narciarskich i snowboardowych są wyszczególnione według koncepcji francuskiej (Kunysz, 2010). Ośrodki sportów zimowych powinny charakteryzować się przestrzenną spójnością i brakiem barier komunikacyjnych oraz harmonijnym zagospodarowaniem. Dotyczy to głównie aspektu własności gruntów wykorzystywanych przez narciarzy. Nawet niewielkie zmiany własności, a co za tym idzie możliwość pojawienia się utrudnień komunikacyjnych na trasach zjazdu, mogą doprowadzić do upadku całego ośrodka (utrudnienia te występują poza regionami, na których funkcjonuje tzw. prawo białego śniegu). Innym wymogiem stawianym przed stacjami narciarskimi jest wyposażenie każdego wyciągu w odpowiednią infrastrukturę usługową (np. gastronomiczną). Również harmonijne połączenie wszystkich rejonów w jeden zespół rekreacyjny przyczyni się do uniknięcia zbędnych ograniczeń w korzystaniu ze wszystkich stoków i umożliwi wprowadzenie skipassów (Nowacki, 2010). Innymi zaleceniem jest odpowiednie wyposażenie najlepszych (najatrakcyjniejszych) tras narciarskich. Zwiększona liczba narciarzy wymaga szerszych nartostrad, lepszego przygotowania tras, odpowiedniego oświetlenia oraz zapewnienia miejsc postoju i wypoczynku dla narciarzy. Ważnym elementem jest również poprawa rzeźby terenu, zarówno w celu ułatwienia zjazdu, jak i jego urozmaicenia. Kolejnym istotnym aspektem funkcjonowania ośrodków narciarskich jest także odpowiednia obsługa osób towarzyszących i turystów, co wpływa na zróżnicowanie oferowanych usług, a zatem organizowanie wypożyczalni sprzętu sportowego i jego serwisu, usług gastronomicznych, parkingów itp. Również coraz częstszym wymogiem stawianym przed właścicielami wyciągów jest zapewnienie miejsc do zabaw i rekreacji dla 
dzieci (stoki do jazdy sankami, snowparki, tzw. ośle łączki) (Havrlant, 2011). Dodatkowo oferta ośrodków narciarskich wzbogacona jest o trasy dla narciarstwa biegowego oraz rozwijane też w Polsce szlaki dla turystyki narciarskiej (Pasławska, 2010).

Tab. 1. Ranking ośrodków narciarskich w Polsce w 2013 roku

\begin{tabular}{|c|c|c|c|c|c|}
\hline M-ce & Ośrodek & Wyciągi i trasy & Infrastruktura & $\begin{array}{c}\text { Komfort jazdy } \\
\text { i wrażenia } \\
\text { narciarskie }\end{array}$ & Suma \\
\hline 1 & Białka Tatrzańska & 80 & 18 & 17 & 115 \\
\hline 2 & Sienna-Czarna Góra & 54 & 18 & 22 & 94 \\
\hline 3 & Krynica-Jaworzyna & 62 & 13 & 18 & 93 \\
\hline 4 & Zieleniec & 61 & 14 & 17 & 92 \\
\hline 5 & Dwie Doliny & 51 & 18 & 22 & 91 \\
\hline 6 & Szklarska Poręba-Szrenica & 49 & 11 & 22 & 82 \\
\hline 7 & Zakopane-Kasprowy & 41 & 10 & 22 & 73 \\
\hline 8 & Korbielów & 46 & 9 & 17 & 72 \\
\hline 8 & Jurgów & 38 & 15 & 19 & 72 \\
\hline 10 & Kluszkowce & 35 & 19 & 17 & 71 \\
\hline 11 & Szczyrk COS & 42 & 9 & 16 & 67 \\
\hline 12 & Szczyrk SON & 39 & 11 & 16 & 66 \\
\hline 13 & Wisła-Cienków & 33,5 & 14 & 17 & 64,5 \\
\hline 14 & Wisła-Soszów & 33,5 & 12 & 18 & 63,5 \\
\hline 15 & Tylicz Ski & 32 & 14 & 16 & 62 \\
\hline 16 & Karpacz-Kopa & 37 & 9 & 15 & 61 \\
\hline 17 & Świeradów Zdrój & 24 & 17 & 19 & 60 \\
\hline 18 & Zakopane-Szymoszkowa & 30,5 & 12 & 17 & 59,5 \\
\hline 19 & Ustrzyki Dolne & 29,5 & 14 & 15 & 58,5 \\
\hline 20 & Wisła-Stożek & 30 & 10 & 18 & 58 \\
\hline 21 & Jaworki & 30,5 & 11 & 16 & 57,5 \\
\hline 22 & Zakopane-Harenda & 28 & 13 & 16 & 57 \\
\hline 23 & Małe Ciche & 25 & 16 & 17 & 56 \\
\hline 23 & Puławy & 26 & 14 & 16 & 56 \\
\hline 25 & Międzybrodzie-Żar & 27,5 & 13 & 14 & 54,5 \\
\hline 26 & Zawoja-Mosorny Groń & 21 & 14 & 18 & 53 \\
\hline 26 & Szczawnica-Palenica & 20 & 13 & 20 & 53 \\
\hline 28 & Karpacz-Biały Jar & 21 & 14 & 16 & 51 \\
\hline 29 & Spytkowice & 17,5 & 15 & 18 & 50,5 \\
\hline 30 & Zakopane-Nosal & 23 & 13 & 14 & 50 \\
\hline
\end{tabular}

Źródło: raport Onetu dotyczący najlepszych ośrodków narciarskich w Polsce w 2013 r. 
Jednakże podstawowym czynnikiem wpływającym na możliwość rozwoju sportów zimowych są odpowiednie warunki naturalne, czyli: obecność pokrywy śnieżnej oraz jej grubość i trwałość, długość utrzymywania się ujemnych temperatur powietrza oraz zróżnicowanie konfiguracji terenu (rzeźba terenu, nachylenie, długość i ekspozycja stoków, pokrycie terenu - roślinność, zabudowa). Obecnie stacje narciarskie mogą występować zarówno na terenach, gdzie walory naturalne tworzą sprzyjające warunki, jak i tam, gdzie brak tych walorów zmusza do stworzenia sztucznych warunków, czego przykładem są planowane całoroczne trasy zjazdowe w Muszynie w Beskidzie Sądeckim.

Ponadto infrastruktura sportowa umożliwia organizowanie imprez sportowych, które stanowią dodatkowy czynnik przyciągający turystów i generują rozwój gospodarczy (Candrea, Ispas, 2010). Organizacja wydarzeń sportowych wpływa również na wizerunek miejscowości oraz przyczynia się do zwiększenia popularności ośrodka. Działania marketingowe prowadzą do wytworzenia się marki turystycznej, stanowiącej ważny element dla rozwoju lokalnego i identyfikacji miejscowości (Stăncioiu i in., 2011).

Według A. Madzikovej (Madziková i in., 2011) oraz K. Krzesiwo i M. Miki (Krzesiwo, Mika, 2011) rozwój turystyki narciarskiej niesie wiele korzyści dla miejscowości i regionów, w których ma on miejsce. Turystyka narciarska wpływa także na wzrost w branżach budowlanej, przemysłowej i transportu. Przyczynia się do rozwoju kulturalnego i socjalnego mieszkańców, zmniejszając emigracje ludności z tych regionów. Powoduje jednakże duże zmiany w środowisku naturalnym. Budowa infrastruktury narciarskiej wymaga wycięcia dużej liczby drzew, czasem nawet części lasu, co zaburza jego mikroklimat (Myga-Piątek, Jankowski, 2009). Inwestycje te budzą wiele obaw i sprzeciwów, gdyż nasilają procesy erozyjne oraz zmniejszają walory przyrodnicze (Wilczek, Palowska, 2004). Na terenach przeznaczonych pod trasy narciarskie następują także zmiany ekologiczne, związane z opóźnioną wegetacją szaty roślinnej. Zjawisko to spowodowane jest długim zaleganiem dużych ilości śniegu wyprodukowanego przez armatki śnieżne i zagęszczonego przez ratraki (Guzik, Skawiński, Wężyk, 2002; Zwijacz-Kozica i in., 2010) i zmienia stosunki hydrologiczne na terenie tras narciarskich.

INFRASTRUKTURA NARCIARSKA W REJONIE PODHALA

Rejon Tatr i Podhala stanowi jeden z najstarszych i najbardziej popularnych regionów narciarskich Polski. Swoją popularność zawdzięcza zarówno warunkom naturalnym, sprzyjającym narciarskim sportom zimowym (klimat i ukształtowanie terenu), jak i walorom kulturowym oraz bogatej infrastrukturze rekreacyjnej. Cechuje się on również stosunkowo dużymi inwestycjami w usługi (Raźniak, 2013b) i względnie niskim poziomem życia, wynikającym m.in. z dostępności różnego rodzaju usług (Winiarczyk-Raźniak, Raźniak, 2011).

Według rankingu popularności ośrodków narciarskich w Polsce (tab. 1) najwyższe miejsce zajmuje położona ok. $20 \mathrm{~km}$ od Zakopanego Białka Tatrzańska. Ta niegdyś spokojna miejscowość agroturystyczna dziś jest jednym z największych centrów narciarskich 
w Polsce, posiadającym również kompleks basenów termalnych. Ośrodek Narciarski Kotelnica Białczańska powstał dzięki wspólnej inicjatywie mieszkańców Białki Tatrzańskiej. Inicjatorami inwestycji byli białczańscy przedsiębiorcy działający w branży turystycznej: Józef Dziubasik i Stanisław Wodziak, którym udało się za niezbyt wygórowaną cenę zakupić kolej krzesełkową i rozpocząć konsultacje z mieszkańcami Białki w celu dzierżawy gruntów pod zamierzoną inwestycję. Dzięki zaangażowaniu mieszkańców to trudne przedsięwzięcie udało się zrealizować. Dolna stacja kolejki została zbudowana obok wyciągu narciarskiego Bania. W ciągu pierwszej dekady XXI wieku Ośrodek Narciarski Kotelnica Białczańska stał się jednym z najnowocześniejszych i największych kompleksów narciarskich w Polsce, który nadal się rozwija (Krzesiwo, Mika, 2011). W centrum miejscowości znajdują się trzy oświetlone wyciągi orczykowe, zlokalizowane przy drodze Białka Tatrzańska-Bukowina Klin.

Również sąsiednia Bukowina Tatrzańska w ostatnich latach stała się mekką dla miłośników sportów zimowych. Na jej terenie zlokalizowanych jest 30 wyciągów narciarskich, które są zróżnicowane co do długości, stopnia trudności i poziomu wzniesień. Nie stanowią one jednak zwartego kompleksu i są rozmieszczone na wielu wzniesieniach. W Bukowinie przeważają wyciągi orczykowe i talerzykowe, występują tam tylko dwie koleje krzesełkowe: na Olczańskim Wierchu i na Rusińskim Wierchu. Zdolność przewozowa wyciągów zależna jest od rodzaju wyciągu, najprostszy talerzykowy przewozi od 200 osób na godzinę, a czteroosobowa kolej krzesełkowa - 2400 osób. Wyciągi znajdujące się w Bukowinie mają od 50 do $700 \mathrm{~m}$ długości, ponadto wszystkie są oświetlone, ratrakowane i w większości naśnieżane. W pobliżu stoków narciarskich znajdują się lokale gastronomiczne, parkingi i wypożyczalnie sprzętu narciarskiego.

Największym ośrodkiem narciarskim Bukowiny Tatrzańskiej jest Stacja Narciarska Rusiń-Ski na Rusińskim Wierchu. Oferuje narciarzom dobre warunki do uprawiania sportów zimowych, m.in. czteroosobową kolej krzesełkową o długości 700 m, dwa wyciągi talerzykowe oraz „babylift” - wyciąg dla małych dzieci. Stok jest sztucznie naśnieżony, oświetlony i ratrakowany. Ośrodek Narciarski Kotelnica dysponuje ośmioma wyciągami, a jeden z nich wyposażony jest w podgrzewane sześcioosobowe kanapy i osłony przeciwwietrzne. Do dyspozycji narciarzy jest osiem tras, z których dwie posiadają homologacje FIS. Ośrodek Narciarski Bania został stworzony z myślą o najmłodszych oraz początkujących narciarzach i snowboardzistach - ze względu na łagodne położenie i długość tras znakomicie nadaje się do stawiania pierwszych kroków. Ośrodek Narciarski Bania jest bezpośrednio połączony z Ośrodkiem Narciarskim Kotelnica Białczańska - posiadają wspólny system jednej karty, karnet TatrySki, obsługujący także inne ośrodki narciarskie, takie jak Hawrań-Ski w Jurgowie, Czorsztyn-Ski w Kluszkowcach i Kaniówka w Białce Tatrzańskiej.

W sąsiedztwie Jurgowa, Białki Tatrzańskiej i Bukowiny Tatrzańskiej znajduje się miejscowość Czarna Góra, w której mieszczą się dwa kompleksy narciarskie Koziniec-Czarna Góra i Grapa Litwinka.

Innymi ośrodkami narciarskimi regionu są: Biały Dunajec z wyciągami Sami Swoi, Toko-Land i U Steni, Małe Ciche z powstałym w 2005 roku nowoczesnym kompleksem narciarskim z kolejką krzesełkową i trzema wyciągami orczykowymi oraz Murzasichle z trasami dla osób początkujących i uczących się jazdy na nartach. 
W miejscowości Witów znajdują się dwa nieduże ośrodki narciarskie: Witów Ski i Witów Biały Potok. W odległości $6 \mathrm{~km}$ od Zakopanego w gminie Poronin znajduje się Stacja Narciarska Suche Ski we wsi Suche. Jest to nowo otwarty w 2012 roku ośrodek narciarski, wyposażony w czteroosobową kolej krzesełkową o długości $950 \mathrm{~m}$ i przepustowości 2200 osób na godzinę.

Natomiast w Nowym Targu znajduje się ośrodek narciarski Długa Polana. Posiada dosyć łagodną trasę o długości 450 m, z dwoma wyciągami orczykowymi.

\section{RoZWÓJ OŚRODKÓW NARCIARSKICH NA PODHALU}

\section{W ŚWIETLE BADAŃ KWESTIONARIUSZOWYCH}

W drugiej części opracowania przedstawiono wyniki badań kwestionariuszowych na temat rozwoju ośrodków narciarskich na Podhalu oraz oczekiwań stawianych przez klientów tych ośrodków. Badania przeprowadzono w 12 ośrodków narciarskich w ośmiu miejscowościach na terenie Podhala (ryc. 2).

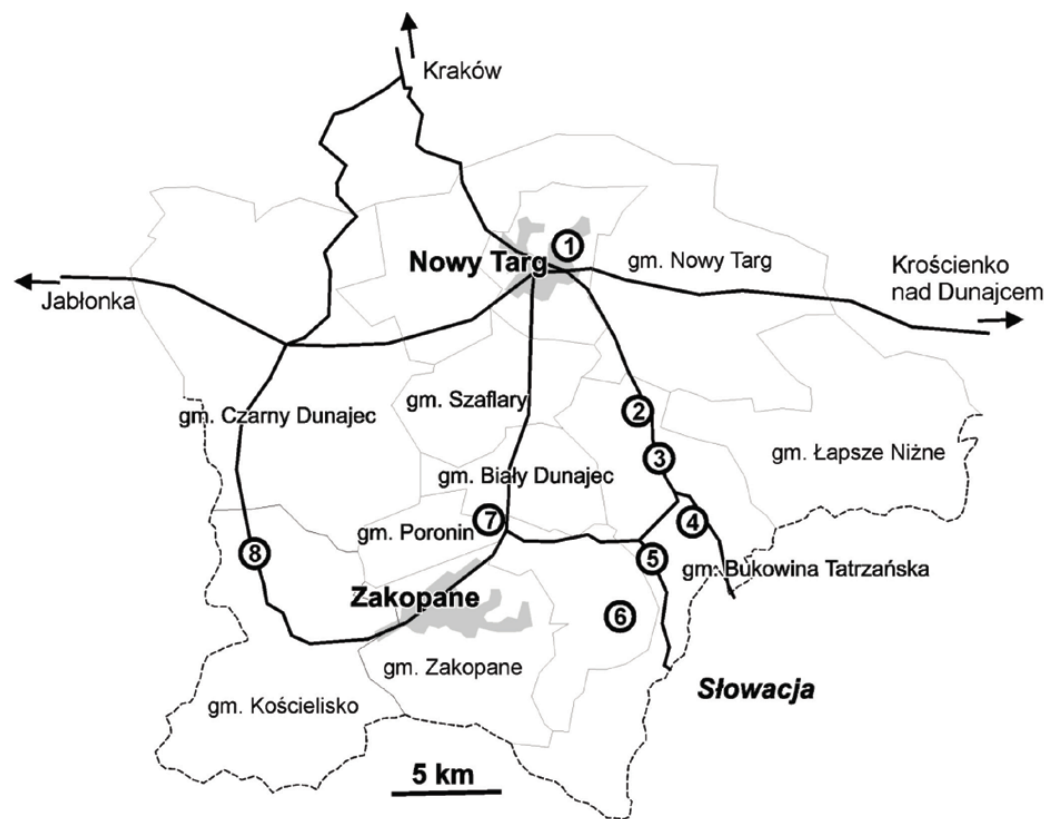

Ryc. 2. Lokalizacja ośrodków narciarskich będących terenem badań kwestionariuszowych

1) Długa Polana w Nowym Targu 2) Kotelnica, Bania i Kaniówka w Białce Tatrzańskiej, 3) ośrodki Koziniec i Grapa w Czarnej Górze, 4) ośrodek Hawrań w Jurgowie, 5) Rusiń-Ski w Bukowinie Tatrzańskiej, 6) Małe Ciche,

7) Suche Ski w Suchem, 8) Witów Ski i Biały Potok w miejscowości Witów 
Infrastruktura narciarska jako ważny element turystyki zimowej wpływa na rozwój usług komplementarnych, takich jak: hotelarstwo, usługi gastronomiczne, wypożyczalnie sprzętu narciarskiego, skuterów śnieżnych, handlu i usług rozrywkowych (Mika i in., 2007). W skład infrastruktury narciarskiej obok wyciągów i tras narciarskich wchodzą armatki śnieżne, zbiorniki retencyjne, przepompownie, system rurociągów zaopatrujących armatki w wodę, drenaże, stacje transformatorowe i systemy kontroli dostępu. Infrastruktura ta pozwala w pewnym stopniu uniezależnić się od opadów śniegu, lecz w dalszym ciągu należy przyjąć, że główną barierą dla rozwoju narciarstwa w Polsce jest temperatura. W przypadku regionu Podhala szczególnie niekorzystne są przypadki ciepłego wiatru halnego, potrafiącego w ciągu kilkudziesięciu godzin pozbawić stoki pokrywy śnieżnej.

Innym ważnym problemem ośrodków narciarskich Podhala, na które wskazywało 91,66\% gestorów, są trudności z uzyskaniem decyzji środowiskowych. Mimo iż wniosek o wydanie takiej decyzji może sporządzić każdy, ponieważ obowiązujące przepisy prawne nie nakładają konieczności posiadania uprawnień do sporządzenia wniosku, nie należy to do rzeczy łatwych, gdyż wymaga specjalistycznej wiedzy z wielu dziedzin. Zgodnie z rozporządzeniem Rady Ministrów z dnia 9 listopada 2010 roku w sprawie przedsięwzięć mogących znacząco oddziaływać na środowisko (Dz.U. nr 213, poz. 1397), infrastruktura narciarska (m.in. trasy, wyciągi, skocznie oraz inne urządzenia, a także urządzenia im towarzyszące) zalicza się do inwestycji mogących zawsze znacząco oddziaływać na środowisko (pierwsza grupa) i mogących potencjalnie znacząco oddziaływać na środowisko (druga grupa). W związku z powyższym wymagają uzyskania decyzji o uwarunkowaniach środowiskowych. Artykuł 74 ww. rozporządzenia precyzuje załączniki potrzebne do złożenia wniosku o wydanie decyzji. Najważniejszym załącznikiem jest karta informacyjna przedsięwzięcia, która zawiera podstawowe dane o planowanej inwestycji, m.in.: opis lokalizacji, rodzaj i skalę przedsięwzięcia. Dane zawarte w karcie umożliwiają właściwym organom administracji podjąć decyzję o konieczności bądź rezygnacji z przeprowadzania oceny oddziaływania na środowisko dla danej inwestycji (DIŚ-ZPI.403.30.2013.MaZak.1 Generalna Dyrekcja Ochrony Środowiska, Warszawa, 2.04.2013). Ocena oddziaływania na środowisko służy do zdiagnozowania, zminimalizowania bądź wyeliminowania oddziaływania na środowisko. W 2011 roku Regionalne Dyrekcje Ochrony Środowiska w południowej Polsce podały, iż za okres dwóch lat przyjęły do rozpatrzenia 26 wniosków, z czego 21 uzgodniono, cztery sprawy były wówczas w toku, a jedna z województwa dolnośląskiego nie została uzgodniona (Generalna Dyrekcja Ochrony Środowiska). Planowanie przestrzenne również stanowi barierę rozwojową. Należy zauważyć, iż ze względu na rozległe ekspozycje krajobrazu górskiego ingerencja w tym obszarze jest widoczna z dużej odległości. Infrastruktura narciarska niesie ze sobą nie tylko elementy wyciągów czy oświetlenia, ale również budynki gospodarcze i usługowe, które nierzadko są niezharmonizowane nie tylko ze sobą, lecz także z krajobrazem. Następuje konfliktowość przestrzeni - im większa atrakcyjność krajobrazu, tym bardziej przestrzeń ta jest interesująca dla inwestorów, a zarazem narażona na zagospodarowanie niezgodne z jej walorami, tzw. zawłaszczenie przestrzeni przyrodniczej (Sołtys, 2009; Quirini-Popławski, 2011). Uzyskanie decyzji o pozwoleniu na budowę pozwala na podjęcie pierwszych kroków związanych z ostateczną realizacją inwestycji. Niemniej jednak zgodnie 
z tym, co podają właściciele badanych stacji, jest to droga przez mękę, trwająca latami. Na przykład prezes Ośrodka Narciarskiego Hawrań w Jurgowie wskazał, iż wszystkie procedury związane z uzyskaniem decyzji o pozwoleniu na budowę zajęły siedem lat. Natomiast budowa kolei krzesełkowej w ośrodku Kaniówka wraz z uzyskaniem potrzebnych pozwoleń zajęła cztery lata. Właściciel Ośrodka Narciarskiego Biały Potok w Witowie zrezygnował z budowy wyciągu orczykowego, nie uzyskawszy w ciągu czterech lat stosownych zezwoleń, co doprowadziło do wygaśnięcia wcześniej uzgodnionej dokumentacji.

Inna bariera rozwoju infrastruktury narciarskiej wg badanych właścicieli ośrodków narciarskich to „brak pewności co do przyszłości, na co składają się coroczne problemy związane z dzierżawą gruntów”. Przykładem może być brak porozumienia pomiędzy właścicielami gruntów a Gliwicką Agencją Turystyczną, co doprowadziło do wyłączenia niektórych wyciągów narciarskich w Szczyrku (Mika i in., 2007). Również brak porozumienia pomiędzy gestorami a jednym z właścicieli gruntów spowodował, że nie uruchomiono stacji narciarskiej Maciejowa w sezonie 2013/14. Głośny był też medialnie przypadek Gubałówki. Właściciel ośrodka narciarskiego Biały Potok w Witowie wskazał, że już dwukrotnie w ciągu ostatnich lat był zmuszony do przestawiania wyciągu orczykowego, z uwagi na brak zgody na dzierżawę gruntów przez ich właścicieli. Wskazany przez niego problem zniechęcił go do realizacji nowego przyłącza energetycznego, które wiązałoby się z koniecznością budowy ok. kilometrowej sieci przez teren działek, na które musiałby uzyskać kilkadziesiąt pozwoleń. Właściciel tego ośrodka wskazuje, że problem z dzierżawami gruntów leży nie tylko w niechęci ich właścicieli, lecz również w zaniedbaniach związanych z regulacją stanu prawnego działek w księgach wieczystych, gdzie niejednokrotnie jako właściciele widnieją ludzie nieżyjący od kilkudziesięciu lat. Z tym problemem dobrze poradzili sobie w 2000 roku właściciele Kotelnicy w Białce Tatrzańskiej, gdzie dzięki pomocy ówczesnego sołtysa, który wyjechał do Chicago w celu podpisania umów dzierżawy z właścicielami gruntów przebywającymi w większości w USA, udało się podpisać 60 umów. Z kolei właściciel ośrodka Biały Potok, jak i wielu innych, liczy na wprowadzenie tzw. prawa śniegu, czyli ustawy o korzystaniu z nieruchomości do celów związanych z narciarstwem, której projekt spoczywa w sejmie. W uzasadnieniu do projektu wskazano, iż wcześniejszy brak uregulowań prawnych w tej kwestii był hamulcem rozwojowym dla dużych stacji narciarskich i blokadą dla nowo powstających. Miałoby to dotyczyć ustanawiania służebności gruntowej na cudzej, sąsiedniej nieruchomości. Zgodnie z projektem, ustanowienie prawa śniegu winno nastąpić w drodze umowy, a w przypadku braku porozumienia stron - przymusu sądowego. Takie rozwiązania ustawowe znajdują zastosowanie na gruntach rolnych w sezonie zimowym w krajach alpejskich (Mika i in., 2007).

Gestorzy w badanych polskich ośrodkach narciarskich przedstawiali problem związany z podstawą opodatkowania podatkiem od nieruchomości kolejek linowych, który ogranicza ich dochodowość. Według niejasnej definicji budowli zawartej w prawie budowlanym, kolej linowa jest traktowana jako budowla, nie jak urządzenie, i w związku z tym od całości urządzenia, czyli od wartości całej kolei, jest naliczany podatek od nieruchomości. Gdyby kolej wg prawa budowlanego była inaczej kwalifikowana, to opodatkowane byłyby tylko budowle bez urządzeń technicznych. Wojewódzki Sąd Administracyjny w Krakowie w wyroku z dnia 
7.09.2010 (I SA/KR 990) poparł argument Urzędu Skarbowego, stwierdzając, że budowle, takie jak koleje linowe należy traktować jako całość. Nie powinno rozkładać się tego typu obiektów po to, aby opodatkowaniu podlegały tylko ich części budowlane. Inwestycje budowy nowych kolei i wyciągów mieszczą się w kwotach od kilku do kilkudziesięciu mln zł, a $2 \%$ podatku od całej kwoty inwestycji stanowi duże obciążenie dla właścicieli ośrodków narciarskich.

Inwestycje związane z budową i rozbudową infrastruktury narciarskiej wymagają uzyskania odpowiednich pozwoleń. Są to m.in.: decyzja o środowiskowych uwarunkowaniach zgody na realizację przedsięwzięcia, decyzja o pozwoleniu na budowę, pozwolenia związane z dopuszczeniem urządzeń transportu linowego do eksploatacji. Wszelkie prace związane z realizacją przedsięwzięcia należy prowadzić pod nadzorem doświadczonego przyrodnika. Decyzja o warunkach środowiskowych nakazuje, aby pokrywa śnieżna była wystarczająco wysoka, by uniemożliwić narciarzom ścieranie gleby. W zależności od terenu, na którym znajduje się inwestycja, może być zakaz lub ograniczenie montowania i użytkowania nagłaśniania oraz oświetlania stoku, co związane jest z ochroną zwierząt. Zaleca się również coroczne wykaszanie łąk na trasach narciarskich w celu przeciwdziałania eutrofizacji łąk i przemianom florystycznym. Można również wprowadzić regularny wypas na tych terenach zamiast koszenia. Armatki śnieżne powinny być tak umieszczone, aby nie powodowały obladzania okolicznej roślinności i tym samym jej uszkadzania. (Decyzja o środowiskowych uwarunkowaniach zgody na realizację przedsięwzięcia OŚ.62240.4.2012 Bukowina Tatrzańska, 10.01.2013 r.) Na podstawie rozporządzenia Ministra Transportu z dnia 1 czerwca 2006 r. w sprawie warunków technicznych dozoru technicznego w zakresie projektowania, wytwarzania, eksploatacji, naprawy i modernizacji urządzeń transportu linowego, urządzenia transportu linowego, przed dopuszczeniem ich do eksploatacji, wymagają pisemnego zgłoszenia do dyrektora Transportowego Dozoru Technicznego. Dokumentacja potrzebna do zgłoszenia powinna zawierać: nazwę urządzenia i jego systemu, lokalizację, rok budowy, dane dotyczące producenta oraz montującego, położenie poszczególnych stacji (m n.p.m.), różnicę wysokości w metrach, długość trasy, liczbę podpór trasowych, średnie nachylenie trasy, przepustowość i ładowność pojazdu, maksymalną prędkość jazdy (m/s), liczbę pojazdów, udźwig oraz liczbę osób, plan sytuacyjny, urządzenia zabezpieczające, rodzaj wyprzęgieł, dane charakterystyczne dotyczące szczególnych warunków eksploatacji urządzenia, opis trasy, charakterystykę liny, dane dotyczące urządzeń napędowych, urządzeń elektrycznych. Warunkiem dopuszczenia urządzeń transportu linowego do użytku jest deklaracja zgodności WE dla podsystemów i urządzeń bezpieczeństwa, z wyjątkiem urządzeń wprowadzonych do obrotu przed 1 maja 2004 roku. Zarządzenie Ministra Transportu i Gospodarki Morskiej z dnia 5.07.1990 r. w sprawie szczegółowego zakresu działania i organizacji specjalistycznych organów kolejowego dozoru technicznego określa, że osobowe koleje linowe i wyciągi narciarskie podlegają dozorowi technicznemu organów kolejowego dozoru technicznego. Nadzór dotyczy kontroli i stosowania przepisów dotyczących norm i bezpieczeństwa, opracowania projektów przepisów warunków technicznych dla urządzeń oraz współpracy z Urzędem Dozoru Technicznego. 
Badania kwestionariuszowe objęły również 160 losowo wybranych osób, w tym 99 mężczyzn i 61 kobiet w sezonie narciarskim 2011/2012 oraz 2012/2013. Najmłodszy respondent miał 18 lat, natomiast najstarszy - 74. Zakresem badań została objęta infrastruktura narciarska pod względem oceny takich elementów, jak: wyciągi, różnorodność, nachylenie, szerokość i długość tras oraz liczba miejsc parkingowych i koszt karnetu. Badania dotyczyły też usług komplementarnych, takich jak zaplecze gastronomiczne i wypożyczalnia sprzętu. W 10 ośrodkach rozmawiano z 10 losowo wybranymi osobami. Natomiast w przypadku Kotelnicy i Kaniówki w Białce Tatrzańskiej przeprowadzono po 30 kwestionariuszy w każdej z nich. Taki wybór pokierowany był tym, iż oba ośrodki działają w systemie wspólnej karty TatrySki. Systemem wspólnej karty TatrySki objęte są także: Bania, Kotelnica i Kaniówka w Białce Tatrzańskiej oraz Hawrań w Jurgowie i Czorsztyn-Ski w Kluszkowcach.

Wśród respondentów prawie połowę (48,7\%) stanowiły osoby uprawiające sporty zimowe nie dłużej niż 10 lat. Drugie miejsce, z udziałem 35,0\%, stanowili użytkownicy uprawiający sporty zimowe od 10 do 20 lat. Fakt ten świadczy o popularności sportów zimowych głównie wśród ludzi młodych (40\% to respondenci do 30 roku życia) oraz popularności badanych ośrodków wśród osób rozpoczynających przygodę ze sportami zimowymi. W 66,2\% przypadków były to osoby określające swoją sytuację materialną jako dobrą i bardzo dobrą, podczas gdy tylko dwie osoby uznały swoją sytuację za złą. Potwierdza to zainteresowanie aktywnym wypoczynkiem ludzi, którzy osiągnęli niezależność finansową (ok. 70\% respondentów to osoby w wieku od 20 do 40 lat). Najwięcej osób odwiedzających badane stacje przyjechało z rodziną lub znajomymi, ta grupa stanowi 71,25\% badanych osób. Ze szkółkami narciarskimi przyjechało 13,12\% osób, a z innymi zorganizowanymi grupami $14,37 \%$. Najmniejszą grupę (1,25\%) stanowią narciarze, którzy przyjeżdżają na stok sami. Powyższe dane świadczą o bardziej rekreacyjnym niż sportowym charakterze turystyki narciarskiej na Podhalu. Wpływa to zarówno na konfiguracje oferowanych stoków narciarskich, jak i bogatą ofertę usług rozrywkowych i gastronomicznych w regionie.

W ocenie wyciągów 12 badanych ośrodków najlepszą pozycje w przedziale od 1 punktu (minimum) do 5 punktów (maksimum) uzyskały Witów Ski $(4,7)$, Suche Ski $(4,7)$ i Kotelnica $(4,7)$ w Białce Tatrzańskiej. Powyżej średniej, która wyniosła cztery, znalazły się również ośrodki Biały Potok w Witowie, Jurgów, Bania w Białce Tatrzańskiej oraz Grapa w Czarnej Górze. Natomiast najgorszą ocenę uzyskał ośrodek Długa Polana $(2,8)$ w Nowym Targu. Na tak wysoką pozycję wymienionych ośrodków wpłynęła głównie niska cena karnetów. Na drugim miejscu znalazła się ocena różnorodności i szerokości tras, według której na pierwszym miejscu znalazła się Kotelnica $(4,6)$. Również w badaniu długości tras w wybranych ośrodkach najlepiej wypadła Kotelnica $(4,1)$, przy wysokiej pozycji ośrodka w Jurgowie (4,0). Pod względem nachylenia stoku najlepszą ocenę (4,6 pkt) uzyskał ośrodek Biały Potok w Witowie.

W ocenie infrastruktury parkingowej oraz gastronomicznej ośrodki otrzymały zbliżone oceny powyżej 4,0. Również w przypadku wypożyczalni sprzętu sportowego ośrodki oferowały podobny poziom usług. Najniższe oceny otrzymała stacja narciarska Długa Polana w Nowym Targu. O jej niskiej pozycji zadecydowały w głównej mierze wysokie ceny karnetów, brak miejsc parkingowych oraz uboga oferta usługowa. 


\section{WNIOSKI}

Coraz większe zainteresowanie zimową aktywnością fizyczną wśród społeczeństwa wymusza na gminach i prywatnych przedsiębiorcach tworzenie nowej i usprawnianie obecnej infrastruktury narciarskiej. Narciarzy i snowboardzistów nie zadowala już tylko naśnieżny stok i wyciąg, ale oczekują oferty kompleksowych usług. Równocześnie powstaje coraz więcej nowych wyciągów i ośrodków narciarskich. Rosnący ruch turystyczny w okresie zimowym, a także konkurencja ze strony nowych podmiotów krajowych oraz ośrodków zagranicznych, wymusza na właścicielach ośrodków narciarskich Podhala konieczność nowych inwestycji w celu zaspokojenia rosnących potrzeb klientów. Duża konkurencja w tym sektorze zmusza do poszukiwania nowych i innowacyjnych rozwiązań, powodujących usprawnienia i udogodnienia dla użytkowników. Jednym z rozwiązań jest tworzenie rozległych i zróżnicowanych kompleksów narciarskich połączonych zarówno komunikacyjnie, jak i finansowo. Przykładem mogą być ośrodki ze skipassem w Białce Tatrzańskiej. Podobnym przykładem mogą być plany założenia międzynarodowego ośrodka narciarskiego, który połączy Witów i sąsiadującą Orawę (Słowacja), co przyczyni się do lepszego rozwoju obu miejscowości. Z przeprowadzonych badań wynika, że ośrodki narciarskie stają się coraz bardziej dochodowe z uwagi na ich rosnącą popularność. Wiąże się to przede wszystkim z rosnącą popularnością aktywnego wypoczynku oraz struktury klientów, wśród których dominują osoby zamożne, zgłaszające zapotrzebowanie na różne dodatkowe usługi. Z usług komplementarnych wśród respondentów dużym zainteresowaniem cieszą się punkty gastronomiczne, miejsca dla dzieci oraz instruktorzy, natomiast znacznie mniejszym wypożyczalnie sprzętu narciarskiego. Związane jest to zarówno z obniżeniem ceny sprzętu, jak i wzrostem zamożności klientów.

Z przeprowadzonych badań wynika, że głównymi barierami rozwoju ośrodków narciarskich na Podhalu są uwarunkowania prawne i administracyjne. Duża dochodowość inwestycji oraz wzrastający popyt zapewniają szybki zwrot poniesionych nakładów. Większość analizowanych ośrodków posiadała zbliżoną ofertę, która zadowalała ich klientów. Przy ofercie o zbliżonych warunkach narciarskich ważną rolę w konkurencyjności ośrodków stanowi cena i oferowany komfort wypoczynku. Szczególnie odnosi się to do szerokości tras narciarskich, oferty gastronomicznej i usług parkingowych. Związane jest to z faktem, że w ośrodkach coraz większy odsetek klientów stanowią ci, którzy preferują raczej wypoczynek na stoku niż aktywny sport. Wynika to zarówno z poziomu umiejętności narciarskich, jak i dużego udziału wyjazdów rodzinnych z dziećmi.

Można zatem przypuszczać, że jedynie dodatnie temperatury powietrza w zimie mogą ochłodzić rozwój infrastruktury narciarskiej na Podhalu. 


\section{Literatura \\ References}

Baran, M. (1985). Kolejki linowe, wyciagi narciarskie, nartostrady. Warszawa-Kraków: Wyd. PTTK. Candrea, A.N., Ispas, D.A. (2010). Promoting tourist destinations through sport events. The case of Braşov. Journal of Tourism, 10, 61-67.

Chudy-Hyski, D. (2005). Analiza wybranych elementów infrastruktury gmin górskich jako obszarów recepcji narciarstwa w Polsce. Infrastruktura i ekologia terenów wiejskich, 3, 5-17.

Dorocki, S. (2007). Stacja Narciarska „Wierchomla” - lokalny ośrodek aktywizacji gospodarczej. Przedsiębiorczość - Edukacja, 3, 81-87.

Dorocki, S., Brzegowy, P. (2013). Zarys historii uzdrowiskowej Krynicy w XIX w. W: B. Płonka-Syroka, A. Kaźmierczak (red.). Kultura uzdrowiskowa na Dolnym Śląsku w kontekście europejskim. Wrocław: Quaestio, 347-371.

Dryglas, D., Wach, K. (2007a). Klimat dla rozwoju przedsiębiorczości turystycznej w Małopolsce w świetle badań empirycznych. Przedsiębiorczość - Edukacja, 3, 46-51.

Dryglas, D., Wach, K. (2007b). Regional Labour Market and Tourist Enterprises in Malopolska. Economics and Competition Polic, 3(8), 79-86. DOI:10.2139/ssrn.1113483

Guzik, M., Skawiński, P., Wężyk, P., (2002). Oddziaływanie narciarstwa zjazdowego na szatę roślinną Doliny Goryczkowej w Tatrach. W: J. Partyka (red.). Użytkowanie turystyczne Parków Narodowych. Ojców, 723-733.

Havrlant, J. (2011). Kierunki i bariery modernizacji ośrodków sportów zimowych w czeskim regionie turystycznym „Beskidy”. Prace Geograficzne, 125, 77-93.

Helešic, J. (2014). Trendy v rozvoji lyžařských středisek a jejich vliv na cestovní ruch. Referat wygłoszony na konferencji Cestovní Ruch, Hotelnictví a Lázeňství ve Světle Vědeckého Výzkumu A Praxe, 14-15 maja 2014.

Krupa, J., Wołowiec, T. (2010). Uzdrowiska Polski Wschodniej wobec wyzwań rozwojowych - turystyka zrównoważona. W: J. Hermaniuk, J. Krupa (red.), Współczesne trendy funkcjonowania uzdrowisk-klastering. Rzeszów: Instytut Gospodarki Wyższej Szkoły Informatyki i Zarządzania, 7-35.

Krzesiwo, K., Mika, M. (2011). Ocena atrakcyjności turystycznej stacji narciarskich w świetle zagadnienia ich konkurencyjności - Studium porównawcze Szczyrku i Białki Tatrzańskiej. Prace Geograficzne, 125, 95-110.

Kunysz, P. (2010). Stan zagospodarowania zieleńca pod kątem uprawiania snowboardu w opinii ankietowanych snowboardzistów. Rozprawy Naukowe AWF we Wrocławiu, 31, 374-380.

Kurek, W. (2004). Turystyka na obszarach górskich Europy. Kraków: IGiGP UJ.

Madziková, A., Klamár, R., Rosič, M., Kaňuk, J. (2011). Główne kierunki i problemy rozwoju turystyki narciarskiej w Republice Słowackiej. Prace Geograficzne, 125, 111-128.

Mika, M., Krzesiwo, K., Krzesiwo, P. (2007). Współczesne problemy rozwoju ośrodków narciarskich w Polsce - przykład Szczyrku. Prace Geograficzne, 117, 63-77.

Myga-Piątek, U., Jankowski, G. (2009). Wpływ turystyki na środowisko przyrodnicze i krajobraz kulturowy - analiza wybranych przykładów obszarów górskich. Problemy Ekologii Krajobrazu, 25, $27-38$.

Nowacki, M. (2010). Model uwarunkowań cen skipassów w polskich ośrodkach narciarskich. Zeszyty Naukowe Uniwersytetu Szczecińskiego, 591, 435-446.

Olchowik, L. (2006). Wypoczynek z dawką adrenaliny wciąż zyskuje nowych fanów. Wiadomości Turystyczne, 15, 11-12.

Pasławska, M. (2010). Turystyka narciarska jako forma aktywnego wypoczynku w okresie zimy. Turystyka i Zdrowie, 4, 155-163.

Petryszyn, J., Zuzańska-Żyśko, E. (2009). Etapy rozwoju gospodarczego i przestrzennego Ustronia. Geographia. Studia et Dissertationes, 31, 127-145. 
Preisler, M. (2011). Turystyka kwalifikowana jako zjawisko społeczne. Studia Periegetica, Zeszyty Naukowe Wielkopolskiej Wyższej Szkoły Turystyki i Zarzadzania w Poznaniu, 6, 37-43.

Puciato, D. (2010). Determinanty popytu na narciarskie usługi rekreacyjne. Rozprawy Naukowe AWF we Wroctawiu, 31, 357-361.

Pytel, S., Tkocz, M., Zuzańska-Żyśko, E. (2009). Wisła - jeden z ośrodków turystycznych w zapleczu Katowickiego Obszaru Metropolitalnego. W: T. Marszał (red.). Funkcja uslugowa małych miast. Łódź: Uniwersytet Łódzki, 89-107.

Quirini-Popławski, Ł. (2011). Turystyka jako czynnik przemian środowiska przyrodniczego północnej części Beskidów Wschodnich (Ukraina). Czasopismo Techniczne. Architektura 108 (6-A), 271-279.

Raźniak, P. (2013a). Zależność pomiędzy miejscem w międzynarodowych hierarchiach miast a poziomem usług turystycznych. Prace Komisji Geografii Przemystu Polskiego Towarzystwa Geograficznego, 24, 76-90.

Raźniak, P. (2013b). Procesy suburbanizacyjne w regionie miejskim Krakowa na tle rozwoju społeczno-gospodarczego województwa małopolskiego. W: P. Raźniak (red.). Społeczno-ekonomiczne przemiany regionów. Kraków: Oficyna Wydawnicza AFM, 45-66.

Sołtys, J. (2009). Zagospodarowanie turystyczne obszarów górskich a krajobraz - wybrane problemy. Czasopismo Techniczne, 10, 126-130.

Stăncioiu, A.F., Teodorescu, N., Vlădoi, A.D., Băltescu, C. (2011). The Image of the Tourism Destination - a Supporting Element in the Development of the Regional Tourism Brand. Study Case: Muntenia. Theoretical and Applied Economics, 18, 2(555), 139-152.

Raport Turystyka zimowa (2012, 5 listopada). Raport TNS OBOP. Pozyskano z www.wiadomosciturystyczne.pl

Wilczek, Z., Palowska, M. (2004). Ocena przyrodnicza przydatności terenów zlokalizowanych na stokach Dębowca i Szyndzieli dla potrzeb realizacji planowanych tras narciarskich „Sahara” $i$,Dębowiec” w Bielsku-Biatej. Katowice.

Winiarczyk-Raźniak, A., Raźniak, P. (2011). Regional differences In the standard of living in Poland (based on selected indices). Procedia - Social and Behavioral Sciences, 19, 31-36.

Zuzańska-Żyśko, E. (2005). Funkcja turystyczna małych miast województwa śląskiego. W: E. Rydz (red.). Kształtowanie funkcji turystycznych $w$ miejscowościach uzdrowiskowych. Słupsk: PAP, 71-87.

Zuzańska-Żyśko, E. (2006). Małe miasta $w$ okresie transformacji. Studium $w$ regionie ślaskim. Katowice: Wydawnictwo Śląsk.

Zwijacz-Kozica, M., Zwijacz-Kozica, T., Zagajewski B. (2010). Ocena wpływu turystyki i narciarstwa na stan kosodrzewiny w rejonie Hali Gąsienicowej na podstawie zdjęć hiperspektralnych. Nauka a zarzadzanie obszarem Tatr i ich otoczeniem, 2, 81-86.

Sławomir Dorocki, absolwent studiów z zakresu geografii społeczno-ekonomicznej Uniwersytetu Pedagogicznego w Krakowie, doktor nauk humanistycznych w dyscyplinie historia (Instytut Europeistyki - Uniwersytet Jagielloński). Adiunkt w Instytucie Geografii Uniwersytetu Pedagogicznego w Krakowie. Zainteresowania badawcze skupiają się wokół problematyki regionów i procesów regionalizacji społeczno-gospodarczej, ze szczególnym uwzględnieniem zróżnicowania przestrzeni europejskiej oraz procesów integracji europejskiej i uwarunkowań historycznych.

Slawomir Dorocki, graduated from the Pedagogical University of Cracow holds a degree in geography and a Ph.D. title in history (Institute of European Studies at the Jagiellonian University). He is an assistant professor at the Pedagogical University of Cracow in the Institute of Geography. His research interests are tied with regional problems and processes of socio-economic regionalization, with particular emphasis on the diversity of Europe, processes of European integration and historical conditions. 
Piotr Raźniak, dr, adiunkt w Instytucie Geografii Uniwersytetu Pedagogicznego w Krakowie. Do zainteresowań badawczych należą: rankingi miast, problemy funkcjonowania obszarów metropolitalnych, migracje ludności, suburbanizacja.

Piotr Raźniak, PhD is an assistant professor in the Institute of Geography at the Pedagogical University of Cracow. His research interests include: rankings of cities; problems of functioning of metropolitan areas; migrations of population; and suburbanization.

Daniel Obirek, absolwent Krakowskiej Akademii im. A.F. Modrzewskiego (kierunek gospodarka przestrzenna).

Daniel Obirek, graduated from A.F. Modrzewski Krakow University where he studied Spatial Management

\section{Adres/Address:}

Uniwersytet Pedagogiczny w Krakowie

Instytut Geografii

Zakład Przedsiębiorczości i Gospodarki Przestrzennej

ul. Podchorążych 2, 30-084 Kraków, Polska

sdorocki@up.krakow.pl

prazniak@up.krakow.pl 